\title{
Ca Saturation Determines Crop Growth in Acidic Ultisols Derived from Different Parent Materials
}

\author{
Shiwei Zhou ${ }^{a}$, Wenjun Liang ${ }^{b}$, Tingting Zeng ${ }^{b}$, Xiao Liu ${ }^{a}$, Ling Meng ${ }^{c}$, and Xiaoli Bic, * \\ ${ }^{a}$ Key Laboratory of Molecular Module-Based Breeding of High Yield and Abiotic Resistant Plants in Universities of Shandong, \\ School of Agriculture, Ludong University, Yantai, 264025 China \\ ${ }^{b}$ Red Soil Experimental Station, Chinese Academy of Agricultural Sciences, Hengyang, Hunan, 426182 China \\ ${ }^{c}$ Yantai Institute of Costal Zone Research, Chinese Academy of Sciences, Yantai 264003 China \\ *e-mail:xlbi@yic.ac.cn \\ Received November 6, 2020; revised December 15, 2020; accepted December 18, 2020
}

\begin{abstract}
Soil acidity has become a major yield-limiting factor, but it is unclear which acidity indicator is the best to use for estimating crop yield changes. In this study, four $\mathrm{pH}$-adjusted Ultisols derived from different parent materials were used for Chinese cabbage and wheat pot experiments. Structural equation modeling (SEM), Gompertz and linear-plateau models were used to examine main contribution of soil acidity indices and to determine their critical values. The results showed that Ca saturation had the strongest direct effect on crop biomass and thus acted as the most important factor. The critical values of Ca saturation varied slightly with crops and soils, where it was 84.6, 93.5, 95.2 and 82.9\% for Ultisols derived from plate shale, Quaternary red clay, red sandstone and granite, respectively. The critical values of exchangeable $\mathrm{Ca}$ and $\mathrm{Al}$, and $\mathrm{Al}$ saturation and exchangeable $\mathrm{Al}$ : Ca ratio (or $\mathrm{Ca}: \mathrm{Al}$ ratio) were also determined as 8.21 and $0.44 \mathrm{cmol}_{\mathrm{c}} \mathrm{kg}^{-1}$, $6.37 \%$, and 0.069 (or 14.5), respectively. In summary, our findings evidenced that critical Ca saturation has the potential to evaluate the implementation of quality improvement of acidic soils for good crop production.
\end{abstract}

Keywords: exchangeable $\mathrm{Ca}$ : Al ratio, Chinese cabbage, wheat, pot experiments, soil acidity

DOI: $10.1134 / \mathrm{S} 1064229321080020$

\section{INTRODUCTION}

Red soils (Ultisols) are widely distributed in subtropical regions of China and are its main acidic cropland soils, where marked soil acidification has been noted. The topsoil $\mathrm{pH}$ has decreased by an average of 0.85 units over a period of 30 years, and the area of acidic agricultural soils $(\mathrm{pH}<5.5)$ increased from 6.2 million ha in 1980 to 10.3 million ha in 2010 $[8,57]$.

Several studies have shown that crop yields were significantly correlated with soil $\mathrm{pH}$, and therefore critical soil $\mathrm{pH}$ values $(\mathrm{pH}$ threshold) for different crops were determined [4, 12, 28, 31, 59]. For example, Fageria and Baligar [12] showed that the critical $\mathrm{pH}$ values for wheat, common bean, soybean, maize and rice were $6.3,6,5.6,5.4$ and 4.9 , respectively. The critical $\mathrm{pH}$ could be used as a control parameter to determine lime requirement of strongly acidic soils. However, soil acidification resulted in large increases in levels of exchangeable aluminum and manganese (Exch. $\mathrm{Al}$ and Exch. Mn) and decreases in concentrations of exchangeable calcium, magnesium, and potassium (Exch. $\mathrm{Ca}$, Exch. Mg and Exch. K), which decreased significantly soil productivity $[14,19,44$, $45,49]$. It maybe that low soil $\mathrm{pH}$ inhibits crop growth via a main indirect effect on Exch. $\mathrm{Al}$ and/or Exch. $\mathrm{Ca}$. That is, these critical values of Exch. Al and Exch. $\mathrm{Ca}$ clearly deserve more attention in quantifying crop response to soil acidification.

Like critical soil $\mathrm{pH}$, critical Exch. Al values also ranged greatly, from 0.24 to $5.2 \mathrm{cmol}_{\mathrm{c}} \mathrm{kg}^{-1}$, depending on temperate zone, crop type and soil type [35, 36, 41, 42, 53]. For example, Qin and Chen [36] showed that critical Exch. Al was $4.0 \mathrm{cmol}_{\mathrm{c}} \mathrm{kg}^{-1}$ for wheat and $4.8 \mathrm{cmol}_{\mathrm{c}} \mathrm{kg}^{-1}$ for maize, respectively, in Hunan's Ultisol derived from Quaternary red clay, while Baquy et al. [3-5] found that in Anhui's Ultisol derived from Quaternary red clay it was 1.72 and $1.99 \mathrm{cmol}_{\mathrm{c}} \mathrm{kg}^{-1}$, respectively. Further, it was suggested that higher critical Exch. Al content for those acidic soils was mainly attributed to the higher $\mathrm{pH}$ buffer capacity ( $\mathrm{pHBC}$ ), as a consequence of having greater cation exchange capacity (CEC) and higher soil organic matter (SOM) levels [3-5]. These results suggested that critical Exch. $\mathrm{Al}$ may not be a better indicator than critical $\mathrm{pH}$ in determining crop growth. Therefore, some other critical values such as Exch. Ca, Al saturation, Ca saturation, and even $\mathrm{Ca}: \mathrm{Al}$ molar ratio, were used for determining the crop-soil relationship [2, 4, 5, 9, 13, 17, 46]. In Malaysia critical Exch. Ca for rice growth was 
$1.2 \mathrm{cmol}_{\mathrm{c}} \mathrm{kg}^{-1}$ [2], which is comparable to that found by Wei et al. [51] in China's Ultisols $\left(1.25 \mathrm{cmol}_{\mathrm{c}} \mathrm{kg}^{-1}\right)$. Our investigation in Qiyang County, Hunan province, showed that the Exch. Ca content ranged from 0.2 to $70.0 \mathrm{cmol}_{\mathrm{c}} \mathrm{kg}^{-1}$ and 103 out of $275(37.5 \%)$ soil sites had the value below the critical level of $1.25 \mathrm{cmol}_{\mathrm{c}} \mathrm{kg}^{-1}$ (unpublished data). This means that it is better to increase the Exch. Ca content in acidic soils during the crop growth period. Therefore, we assume that crop growth in Hunan's red soils is mainly limited by Exch. $\mathrm{Ca}$ or Ca saturation.

Structural equation modeling (SEM) is an extension of regression and path analysis that can be used to model multivariate relations and distinguish direct from indirect effects of factors. The use of SEM to explore the relationships between ecosystem structure and function has increased dramatically in recent years [11, 26, 38, 54, 56]. However, little research has been conducted examining the relationships among soil $\mathrm{pH}$, Exch. Al, Exch. Ca and crop productivity in acidic Ultisols. The purpose of this study was to: (1) use SEM to explore the direct and indirect effects of soil $\mathrm{pH}$ on crop growth; (2) demonstrate that $\mathrm{Ca}$ saturation is the main factor controlling the crop yield in strongly acidic soils; and (3) establish critical limits of Ca saturation for crop yield on Ultisols derived from different parent materials.

\section{MATERIALS AND METHODS}

Soils. Ultisols originated from four parent materials were collected from different locations of Qiyang County, Hunan Province, China, for this study (plate shale: $26^{\circ} 44^{\prime} 31^{\prime \prime} \mathrm{N}, 111^{\circ} 53^{\prime} 34^{\prime \prime} \mathrm{E}$; Quaternary red clay: $26^{\circ} 35^{\prime} 4^{\prime \prime} \mathrm{N}, 111^{\circ} 46^{\prime} 51^{\prime \prime} \mathrm{E}$; red sandstone: $26^{\circ} 9^{\prime} 14^{\prime \prime} \mathrm{N}$, $112^{\circ} 10^{\prime} 33^{\prime \prime}$ E; granite: $26^{\circ} 9^{\prime} 31^{\prime \prime} \mathrm{N}, 112^{\circ} 8^{\prime} 35^{\prime \prime}$ E). Soil samples were taken from top layer $(0-20 \mathrm{~cm})$, airdried and ground through $1-\mathrm{cm}$ screen for the pot experiment. Their chemical properties were analyzed by the method of Lu [29] and were listed in Table S1. Where effective cation exchange capacity (ECEC) is the sum of exchangeable cations $(\mathrm{Ca}+\mathrm{Mg}+\mathrm{K}+\mathrm{H}+\mathrm{Al})$, and $\mathrm{Al}$ and $\mathrm{Ca}$ saturation were estimated as the proportion of these cations in ECEC [4, 5, 14]. The soil $\mathrm{pHBC}$ was estimated from the slopes of linear portion of titration curves at $\mathrm{pH} 4-6$ [1].

The higher $\mathrm{pHBC}$ of a soil at a given $\mathrm{pH}$, the more resistance it offers to change in $\mathrm{pH}$ following acid or alkali addition. Table $\mathrm{S} 1$ showed Ultisols derived from granite has the lowest $\mathrm{pHBC}\left(11.9 \mathrm{kmol} \mathrm{H} \mathrm{Hg}^{+} \mathrm{pH}^{-1}\right)$, about half of that from plate shale, which was probably mainly contributed to its lowest CEC. Baquy et al. [3-5] considered that soils with higher CEC and higher SOM could be more resistant to changes of soil acidity, viz., higher pHBC. Zhao et al. [55] further evidenced that CEC was the main factor limiting the acidification of Ultisols derived from plate shale, quaternary red clay, red sandstone and granite.
Pot experiments. For each of the four soils, $\mathrm{pH}$ buffer curve was established between $\mathrm{pH} 3$ and 8 by shaking $10 \mathrm{~g}$ of soil for $12 \mathrm{~h}$ in $50 \mathrm{~mL} \mathrm{H}_{2} \mathrm{O}$ with varying amounts of $\mathrm{H}_{2} \mathrm{SO}_{4}$ and $\mathrm{CaO}$ in 15 samples, where each sample was continuously measured at least 5 times. The $\mathrm{pHs}$ were then adjusted to $3-8$ with 14 gradients in $20 \mathrm{~kg}$ of soil by $1 \mathrm{~mol} \mathrm{~L}^{-1} \mathrm{H}_{2} \mathrm{SO}_{4}$ and $\mathrm{CaO}$ based on the $\mathrm{pH}$ buffer curve of each soil before pot experiments. For every soil $\mathrm{pH}$, three replicates were assigned, and every soil was potted at $2.5 \mathrm{~kg}$ per pot, and mixed with mineral fertilizers (urea, calcium superphosphate, and $\mathrm{KCl}$ with $\mathrm{N}: \mathrm{P}_{2} \mathrm{O}_{5}: \mathrm{K}_{2} \mathrm{O}=2: 1: 1$ and application rate of $300 \mathrm{~kg} \mathrm{~N} \mathrm{ha}^{-1}$ ) after it was pre-incubated at $70 \%$ of field water holding capacity in the dark at $25^{\circ} \mathrm{C}$ for 30 days (Chinese cabbage) and 60 days (wheat), respectively. Considering the time effect, we selected $10 \mathrm{pH}$ gradients for each soil for Chinese cabbage experiment $(4 \times 10 \times 3=120$ treatments $)$ and $10-$ 14 gradients for wheat (138 treatments).

4 pre-germinated Chinese cabbage seeds (or 10 wheat seeds) of same size were selected for uniform plant growth. Seeds were sown at the same depth into each pot soil, and each pot was regularly weighed to maintain soil moisture at $70 \%$ of field water holding capacity throughout the trial period. Pots were arranged on a screenhouse in a randomized complete design with three replications per treatment. The plants grew for 30 days and were then harvested, where shoots were oven-dried at $70^{\circ} \mathrm{C}$ for $48 \mathrm{~h}$ and weighed. At that time, soil samples were collected from each pot separately, air-dried, and ground to pass through a $0.25-\mathrm{mm}$ sieve for measuring soil $\mathrm{pH}$, exchangeable acidity and base cations.

Additionally, after 30 days of incubation (before beginning the pot experiment) the soils were also sampled to determine soil acidity and exchangeable cations.

Soil analysis. According to the method of Lu [29], soil $\mathrm{pH}$ was measured with a pHSJ-4F meter (INESA, Shanghai, China) in a $1: 2.5$ soil/water suspension. The exchangeable acidity (Exch. Al + Exch. H) was extracted with $1.0 \mathrm{M} \mathrm{KCl}$ and then titrated by $0.02 \mathrm{M} \mathrm{NaOH}$ to $\mathrm{pH}$ 7.0. $1 \mathrm{M} \mathrm{NaF}$ was added to part of the extract, followed by titration with $0.02 \mathrm{M} \mathrm{NaOH}$ to determine Exch. H. Exch. Al was calculated as the difference between exchangeable acidity and Exch. $\mathrm{H}$. Exchangeable base cations were extracted with $1.0 \mathrm{M}$ ammonium acetate at $\mathrm{pH} 7.0$, and then $\mathrm{Ca}$ and $\mathrm{Mg}$ were determined using atomic absorption spectrometry (ZEEnit700P, Analytik Jena, Germany) and only $\mathrm{K}$ (no detectable $\mathrm{Na}$ ) with flame photometry (6400A, INESA, Shanghai, China).

ECEC, $\mathrm{Al}$ and $\mathrm{Ca}$ saturation and Exch. $\mathrm{Al}$ : Ca ratio were calculated using the following formulas [4, 5, 14]:

$$
\begin{gathered}
\text { ECEC }\left(\mathrm{cmol}_{\mathrm{c}} \mathrm{kg}^{-1}\right)=\text { Exch. } \mathrm{Ca}+\text { Exch. } \mathrm{Mg} \\
\quad+\text { Exch. } \mathrm{K}+\text { Exch. } \mathrm{H}+\text { Exch. } \mathrm{Al}, \\
\text { Al saturation }(\%)=\text { Exch. Al/ECEC } \times 100
\end{gathered}
$$


Table 1. The goodness of fit parameters of SEMs for Chinese cabbage and wheat

\begin{tabular}{l|c|c|c}
\hline \multicolumn{1}{c|}{ Index } & Acceptable & Chinese cabbage & Wheat \\
\hline$P$-value & $>0.05$ & 0.265 & 0.057 \\
$\chi^{2}$ & - & 15.72 & 23.238 \\
$\mathrm{df}$ & - & 13 & 14 \\
$\chi^{2} / \mathrm{df}$ & $<3.00$ & 1.21 & 1.66 \\
NNFI & $>0.90$ & 0.996 & 0.989 \\
CFI & $>0.90$ & 0.999 & 0.996 \\
RMSEA & $<0.08$ & 0.042 & 0.069 \\
GFI & $>0.95$ & 0.973 & 0.964 \\
NFI & $>0.95$ & 0.992 & 0.989 \\
\hline
\end{tabular}

Ca saturation $(\%)=$ Exch $. \mathrm{Ca} / \mathrm{ECEC} \times 100$,

Exch. $\mathrm{Al}: \mathrm{Ca}$ ratio $=$ Exch. $\mathrm{Al} /$ Exch. $\mathrm{Ca}$.
Data analysis. In order to avoid bias among Ultisols derived from different parent materials, relative yield of shoot dry weight was calculated by the following formula:

$$
\text { relative yield }(\%)=\frac{\text { actual yield of shoot dry matter }}{\text { an average for the maximum yield treatment }} \times 100
$$

Gompertz model and linear-plateau model could simulate the relationships between crop yield and soil $\mathrm{pH}$, in which critical $\mathrm{pH}$ values were determined. Gompertz equation was described as follows:

$$
y=a \times \exp \left\{-\exp \left[-\frac{\left(x-x_{0}\right)}{b}\right]\right\}
$$

where $a$ is asymptotic value, i.e., maximum yield reached; $b$ is a parameter relating to slope of the curve; $x_{0}$ is inflection point where the curve reaches its maximum slope, that is, $x_{0}$ is most sensitive to changes in $\mathrm{y}$ $[10,21,32,39]$. Accordingly, critical soil pH, corresponding to $90 \%$ of maximum yield, was calculated using the following equation:

$$
x=-\ln (-\ln 0.9) b+x_{0}=2.25 b+x_{0} .
$$

The linear-plateau equation was described below:

$$
y=\left\{\begin{array}{ll}
a+b \times x & x \leq x_{0} \\
c & x>x_{0}
\end{array},\right.
$$

where $a$ is the intercept and $b$ is the slope of the line; $c$ is the plateau value (maximum or minimum yield), and $x_{0}$ is determined as the intersection point of two linear lines representing critical or threshold value [27, $31,35,48,50]$.

The SEM analyses were performed using AMOS 17.0 (IBM-SPSS Inc., Chicago, USA). Spearman correlation analysis, stepwise multiple regression analysis, and curve fitting were performed using SPSS 17.0 (IBM-SPSS Inc., Chicago, USA). Results were plotted using SigmaPlot 12.0 (Systat Software Inc., San Jose, USA).

\section{RESULTS}

Direct and indirect effects of soil acidity indices on crop growth. To examining the multivariate relations between soil acidity indices and crop yield, and quantifying their direct and indirect effects, a SEM model was built and presented in Fig. 1 and Table 1. The $P$ values were not significant for Chinese cabbage $(P=0.265)$ and wheat $(P=0.057)$, supporting the established models. Additionally, Hoe [23] proposed that the ideal fit indices are Non-Normed Fit Index (NNFI) and Comparative Fit Index (CFI) $(>0.90$ indicates good fit), Root Mean Square Error of Approximation (RMSEA) $(<0.08$ indicates acceptable fit), and $\chi^{2}$ statistic ( $\chi^{2} / \mathrm{df}$ ratio of 3 or less). Zhu et al. [58] considered that a good fitting model must also have higher Goodness of Fit Index (GFI) and Normed Fit Index (NFI) (>0.95). In our study, all values were in the acceptable interval, further demonstrating the soundness of the models.

As shown in the SEM models, the total effect of soil $\mathrm{pH}$ on crop production was the strongest, with 0.84 for Chinese cabbage and 0.77 for wheat; however, its direct effect was only $0.33(39.3 \%)$ and $0.20(26.2 \%)$, respectively. That is, major crop yield losses in acidic soils would come from the indirect effects due to changes in soil properties rather than direct effects due to $\mathrm{pH}$ decrease. Further, Ca saturation had the strongest direct effect on crop biomass ( 0.53 for Chinese cabbage and 0.51 for wheat, respectively), suggesting that it was the most important factor determining crop growth in acidic soils. 


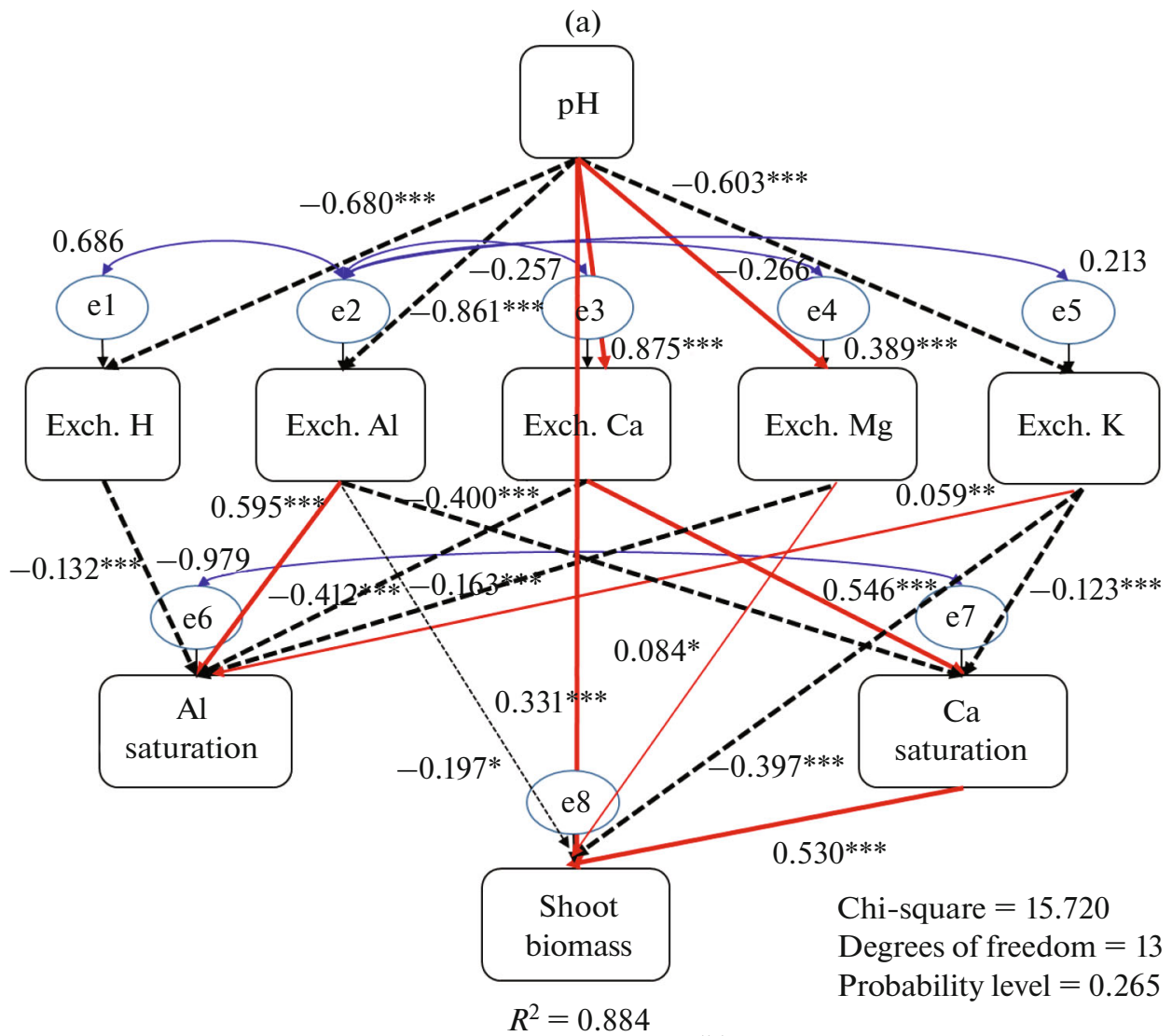

(b)

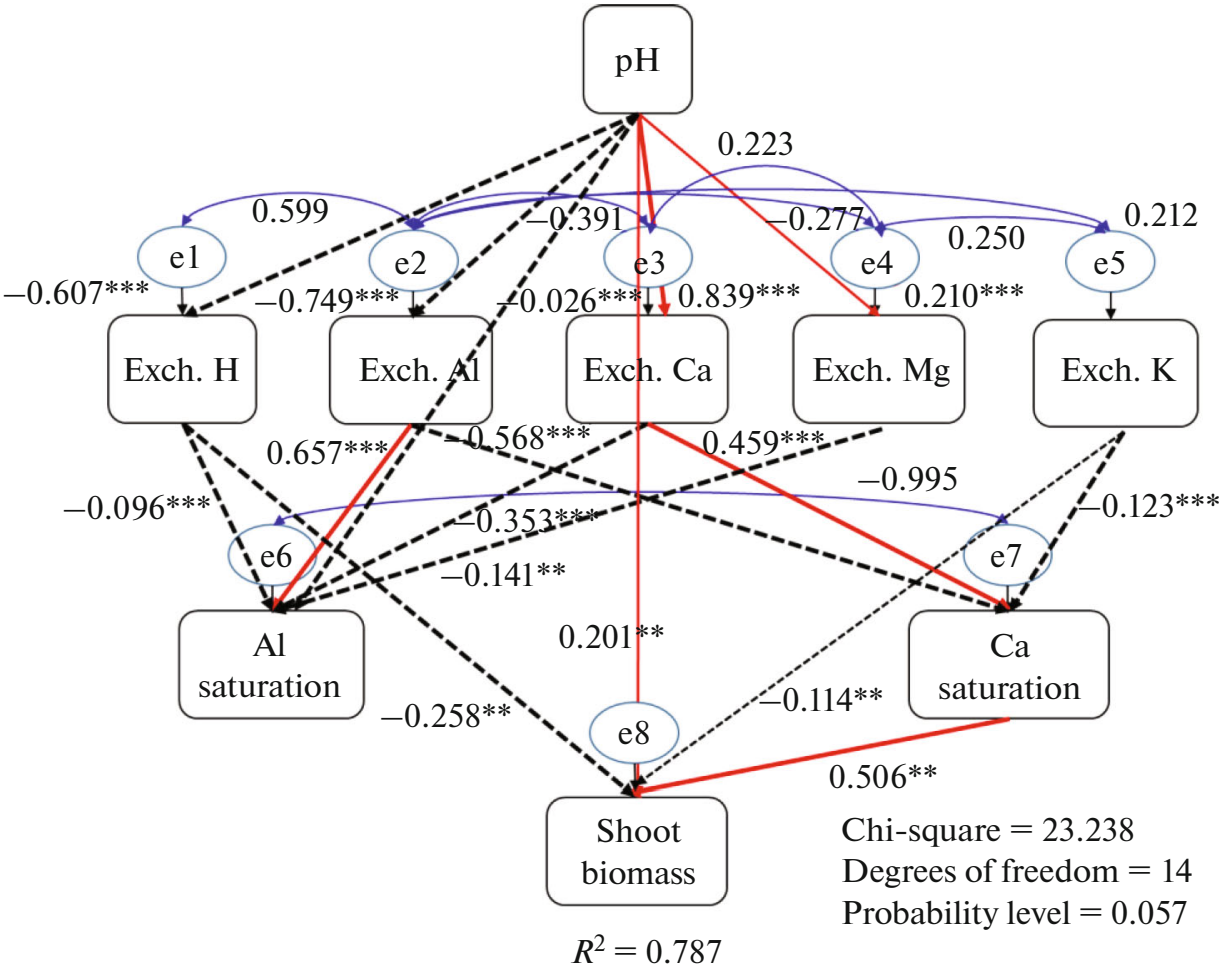

Fig. 1. Model results for (a) Chinese cabbage and (b) wheat. Single arrows represent the direct pathway of one variable to another, and double arrows represent the correlation between two variables. The width of solid and dotted arrows indicated the strength of the positive and negative relationships, respectively. The standardized path coefficients are listed beside the lines $(* * *, * *$, and $*$ indicated significant at $0.001,0.01,0.05$, respectively). 

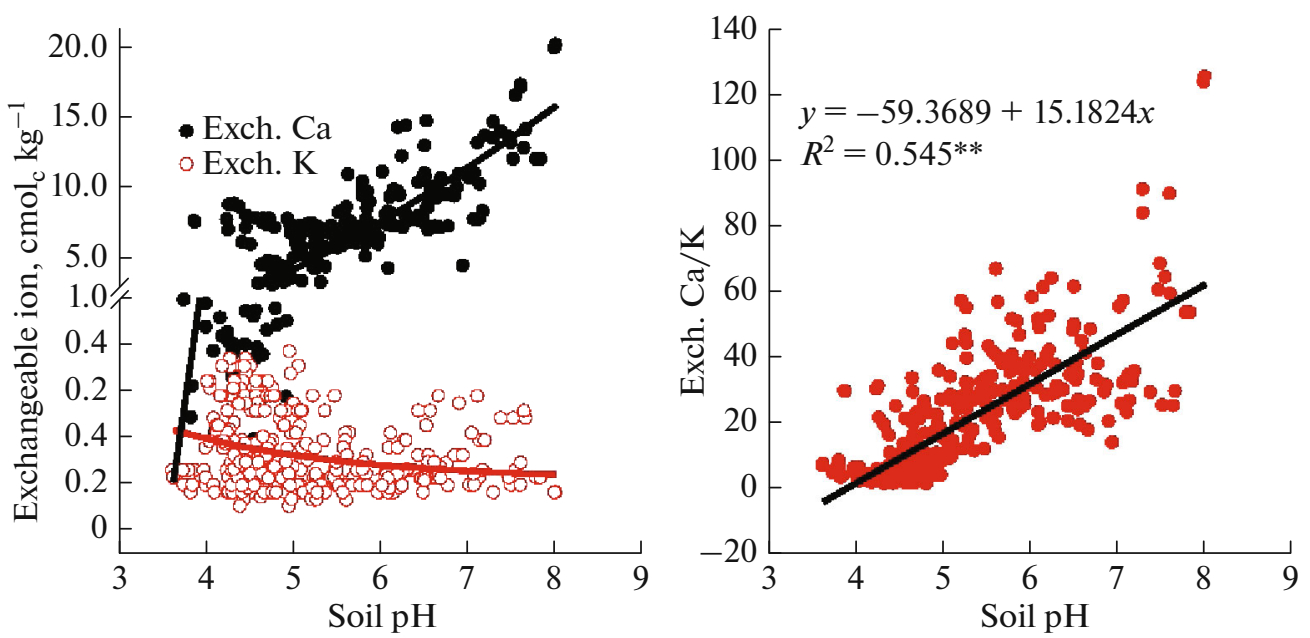

Fig. 2. The relationships between soil $\mathrm{pH}$ and Exch. Ca, Exch. K, and Exch. Ca/K.

It is worth noting that Exch. $\mathrm{K}$ exerted a significantly negative direct effect on crop growth in acidic soils $(-0.397$ for Chinese cabbage and -0.114 for wheat, respectively). This perhaps means that potassium fertilization at a rate of $150 \mathrm{~kg} \mathrm{~K}_{2} \mathrm{O} \mathrm{ha}{ }^{-1}$ in acidic upland soils might be excessive, which led to increasing Exch. $\mathrm{K}$ and decreasing Exch. Ca in soils, and further declining crop yields as the consequence of an increase in calcium deficiency in crops. Gülser et al. [18] showed that NPK fertilization to acidic soils caused $\mathrm{Ca}$ and $\mathrm{Mg}$ (in particular $\mathrm{Ca}$ ) deficiency in the grain, where grain yield showed negative correlation with $\mathrm{K}$ and positive correlation with $\mathrm{Ca}$ contents. Fekadu et al. [15, 16] supported that excessive soil K inhibited $\mathrm{Ca}$ uptake by crops, and thus, the yield decreased greatly. For production of annual crops, ratio ranges of 17 to 32.5 for $\mathrm{Ca} / \mathrm{K}$ in soils are needed. In our study here, Exch. $\mathrm{Ca} / \mathrm{K}$ was very lower in strong acidic soils (e.g., less than 5 at $\mathrm{pH} 4$ ) than the proposed values (Fig. 2). It at $\mathrm{pH}$ exceeding 5 only could be considered as the favorable ratio due to the increase in Exch. Ca and the decrease in Exch. K. In short, for strong acidic soils, Ca deficiency is the main problem, and chemical fertilization (in particular $\mathrm{K}$ fertilizers) aggravates the problem. Therefore, increasing micronutrients such as $\mathrm{Ca}$ is more important than increasing macronutrients in strong acidic soils.

The significant variables (crop yield and soil acidity indices with a minimum collinearity by excluding those variables with eigenvalues close to 0 and condition index $>10$ ) were entered into a stepwise regression which produced 2 models, which revealed that Ca saturation was the most important, and explained 73 to $75 \%$ of the variance in crop yield (Table 2), which was consistent with the results of SEMs. These results all together therefore emphasized that quantifying optimum Ca saturation as an accurate representation of soil acidity indices is essential to understand crop response to soil acidification for obtaining maximum crop production.

Critical limit of Ca saturation in Ultisols. There were significant linear relations between crop growth and Ca saturation in soils, and the average slope of the lines was 1.1, except for Ultisol derived from plate shale in which a higher linear slope of 3.2 was found (Fig. 3). This suggested that the rate of crop yield increase with increase in Ca saturation was steeper in Ultisol derived from plate shale compared to other parent materials.

Based on linear regression analysis, the critical $\mathrm{Ca}$ saturation level (at $90 \%$ of maximum yield) in Ultisols for Chinese cabbage and wheat was determined and listed in Table 3. Herein, maintaining soil Ca saturation above $80 \%$ was crucial important for the achievement of high crop yield in acidic soils. However, a bigger difference was seen in critical Ca saturation among soils compared to that in crops, where Ultisol derived from granite had a relatively low $\mathrm{Ca}$ saturation requirement of $83 \%$ whereas it from quaternary red clay had higher critical value (about $94 \%$ ). The main difference between the two soils is a higher SOM content $\left(39.9 \mathrm{~g} \mathrm{~kg}^{-1}\right)$ in the former compared to $16.3 \mathrm{~g} \mathrm{~kg}^{-1}$ in the latter, which maybe lead to a larger increase in the resistance of crops to $\mathrm{Al}$ and $\mathrm{H}$ toxicity in acidic soils [20, 22, 43, 47].

Other critical soil indicators for crop growth in Ultisols. Although some distributions are not normal (Fig. S1), soil pH plays an important role in crop growth in acidic soils, and significantly correlates with all acidity indices, in particular with Exch. $\mathrm{Ca}$, Exch. $\mathrm{Al}, \mathrm{Ca}$ and $\mathrm{Al}$ saturation, and Exch. $\mathrm{Al}$ : $\mathrm{Ca}$ ratio (Table 4). Therefore, it is useful to determine the critical soil $\mathrm{pH}$ levels and other acidity indices values $[2$, $4,5,13,17,22,46]$. Herein, critical values of soil $\mathrm{pH}$, Exch. Ca, Exch. Al, Al saturation, and Exch. Al : Ca ratio (or $\mathrm{Ca}: \mathrm{Al}$ ratio) were calculated according to 

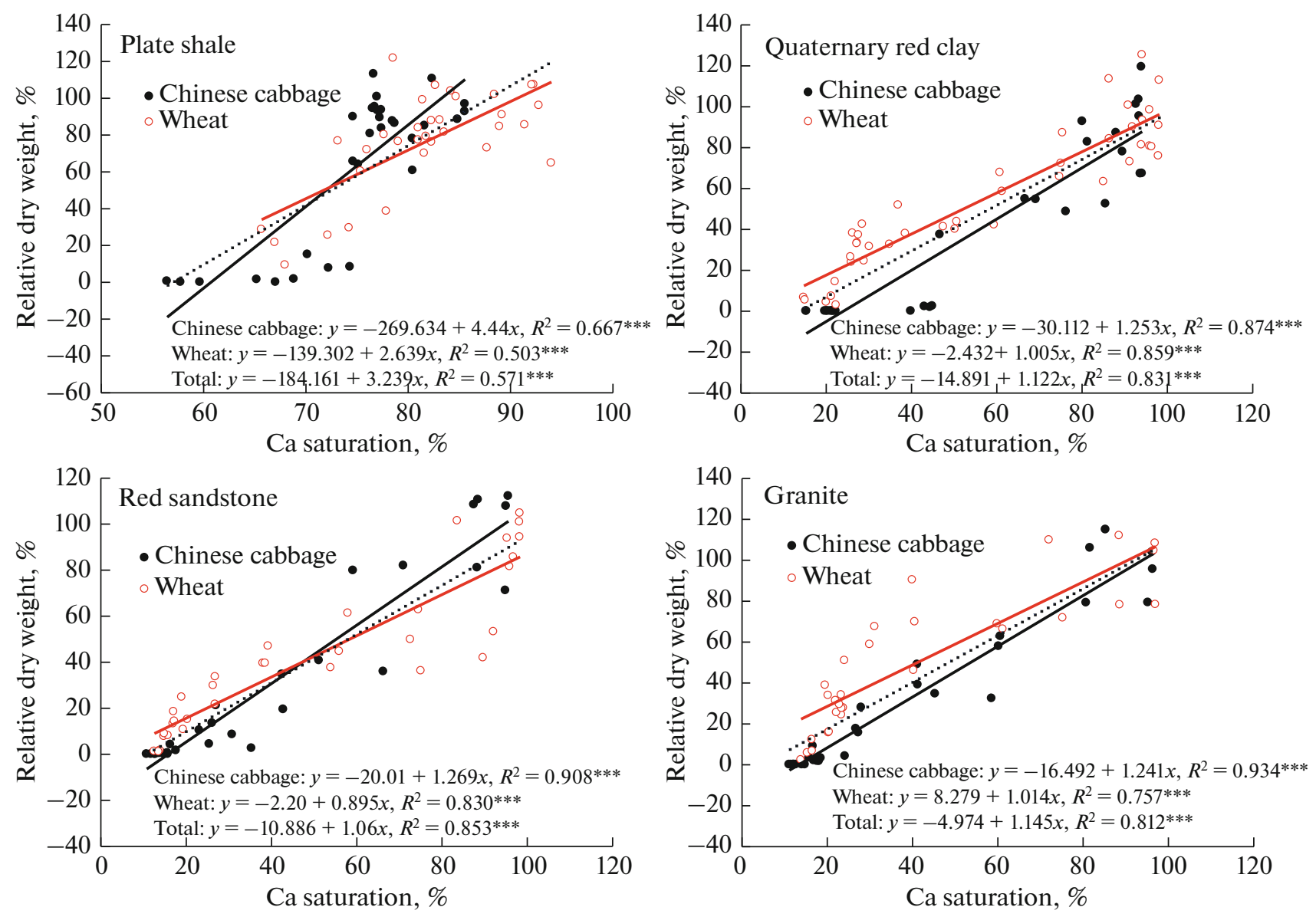

Fig. 3. Observed (symbols) and predicted (lines) relationships between shoot dry weights of Chinese cabbage (solid circles) and wheat (open circles) and Ca saturation.

crop response to individual soil indices (Gompertz model or linear-plateau model) (Fig. S2-S6 and Table 5 and S2).

Some were reasonable and some were not. For example, the values obtained for critical Exch. $\mathrm{Al}: \mathrm{Ca}$ ratio by three methods in Ultisol derived from plate shale were similar $(0.011 \sim 0.012$ for Chinese cabbage and $0.019 \sim 0.023$ for wheat, respectively), whereas a significant (by several times) difference was found in Ultisol derived from red sandstone (from 0.056 to

Table 2. Stepwise regression analysis of influence of soil acidity indices on crop growth in acidic Ultisols

\begin{tabular}{|c|c|c|c|c|c|c|c|}
\hline \multirow{2}{*}{ Crop } & \multirow{2}{*}{\multicolumn{2}{|c|}{ Model }} & \multicolumn{4}{|c|}{ Coefficient } & \multirow{2}{*}{$R^{2}$} \\
\hline & & & B & SE & standardized & Sig. & \\
\hline \multirow{4}{*}{ Chinese cabbage } & \multirow{2}{*}{1} & Ca Saturation & 1.213 & 0.063 & 0.870 & 0.000 & \multirow{2}{*}{0.757} \\
\hline & & Constant & -22.278 & 3.813 & & 0.000 & \\
\hline & \multirow{2}{*}{2} & $\begin{array}{l}\text { Ca Saturation } \\
\text { Exch. K }\end{array}$ & $\begin{array}{r}0.833 \\
-97.112\end{array}$ & $\begin{array}{r}0.066 \\
11.168\end{array}$ & $\begin{array}{r}0.598 \\
-0.412\end{array}$ & $\begin{array}{l}0.000 \\
0.000\end{array}$ & \multirow{2}{*}{0.852} \\
\hline & & Constant & 41.042 & 7.870 & & 0.000 & \\
\hline \multirow[b]{3}{*}{ Wheat } & \multirow{2}{*}{1} & Ca Saturation & 0.947 & 0.049 & 0.855 & 0.000 & \multirow{2}{*}{0.731} \\
\hline & & Constant & 1.258 & 3.222 & & 0.697 & \\
\hline & 2 & $\begin{array}{l}\text { Ca Saturation } \\
\text { Exch. H } \\
\text { Constant }\end{array}$ & $\begin{array}{r}0.738 \\
-30.884 \\
24.106\end{array}$ & $\begin{array}{l}0.067 \\
7.107 \\
6.067\end{array}$ & $\begin{array}{r}0.666 \\
-0.262\end{array}$ & $\begin{array}{l}0.000 \\
0.000 \\
0.000\end{array}$ & 0.764 \\
\hline
\end{tabular}


Table 3. Critical Ca saturation (\%) for crop growth in Ultisols

\begin{tabular}{l|c|c|c}
\hline \multicolumn{1}{c|}{ Parent material } & Chinese cabbage & Wheat & Total \\
\hline Plate shale & 81.0 & 86.9 & 84.6 \\
Quaternary red clay & 95.8 & 91.9 & 93.5 \\
Red sandstone & 86.7 & 100 & 95.2 \\
Granite & 85.8 & 80.6 & 82.9 \\
\hline
\end{tabular}

0.13 for Chinese cabbage and from 0.055 to 0.31 for wheat, respectively). Not only that, more differences were also observed in these critical values for different crops and soils (Table 5 and S2). For example, the critical values of $\mathrm{Al}$ saturation and Exch. $\mathrm{Al}: \mathrm{Ca}$ ratio for wheat on Ultisols ranged from 1.69 to $9.52 \%$, and from 0.023 to 0.46 , respectively; the highest values were observed in Ultisol derived from granite. Another example was critical soil $\mathrm{pH}$ in Ultisol derived from red sandstone which was determined as 5.7 and 7.2 for Chinese cabbage and wheat, respectively.

Our study showed that these fit indices were not as good as Ca saturation, but they gave generally consistent results, where lower soil pH, lower Exch. Ca and $\mathrm{Ca}$ saturation, and consequently, higher Exch. $\mathrm{Al}$ and $\mathrm{Al}$ saturation and Exch. $\mathrm{Al}$ : Ca ratio in Ultisol derived from granite were considered to be tolerable by plants, but just the opposite happened in Ultisol derived from quaternary red clay.

\section{DISCUSSION}

The limit of practical application of some critical indicators such as soil $\mathbf{p H}$ and Exch. Al. As above stated, the direct effects of soil $\mathrm{pH}$ on crop growth were smaller, suggesting that the relationships between crop yield and soil pH were weaker (Table 4). Determination of critical soil $\mathrm{pH}$ using this regression model resulted in greater error, and hence, the predicted critical values deviated significantly from reality. Therefore, the accuracy of this indicator should be questioned, and, more importantly, our results and many previous research showed that the critical soil $\mathrm{pH}$ values varied greatly depending on crops and soils [4, 12, 28, 31, 59]. For example, Liu et al. [28] found that critical $\mathrm{pH}\left(0.01 \mathrm{M} \mathrm{CaCl}_{2}\right)$ for wheat ranged from 4.3 (Brucedale, calcic paleustalf) to 5.6 (Borambola, aeric albaqualf), giving a $1.3 \mathrm{pH}$ unit difference. Baquy et al. [3] found on the same soil type (e.g., Ultisol) that there were also greater differences in the critical soil $\mathrm{pH}$ values for wheat and canola, ranging from 4.66 and 4.87 from Anhui to 5.29 and 5.65 from Hunan, respectively. Undoubtedly, wide range of critical soil pH values, as well as its variability, were often confusing and difficult for the practicing farmers to carry out the acidic soil improvement for a practical application.

Al toxicity in acidic soils is a primary factor limiting root growth, mineral nutrient uptake and thus crop productivity [22, 25, 37, 45]. So, Exch. Al, in particu- lar Al saturation, not only showed better relationship with crop yield but also was a better indicator for predicting crop response to liming, compared with soil $\mathrm{pH}[4,46]$. Even critical Exch. Al and $\mathrm{Al}$ saturation were determined by Baquy et al. [4] as 1.04$1.99 \mathrm{cmol}_{\mathrm{c}} \mathrm{kg}^{-1}$ and $12.51-15.16 \%$, respectively, for maize in Ultisols. Smyth and Cravo [46] also estimated that critical $\mathrm{Al}$ saturation in Oxisol was $27 \%$ for maize and soybean, and $54 \%$ for peanut, respectively. These values were obviously higher than that obtained in our study $(0.89-6.98 \%$ for Chinese cabbage, and 1.69-9.52\% for wheat) (Table 5). This suggests two possibilities: (1) like critical soil $\mathrm{pH}$, critical Exch. Al or Al saturation showed wider range of variation among both soils and crops, which turned out to be largely limited to a given soil \& crop, or (2) the smaller contribution of Exch. Al or Al saturation to crop yield resulted in a higher bias and hence, a lower fitting precision of the linear-plateau model, so it is difficult to obtain accurate parameters, viz., critical Exch. $\mathrm{Al}$ and $\mathrm{Al}$ saturation. These would greatly restrict their practical application.

Furthermore, $\mathrm{Al}$ toxicity occurs often at soil $\mathrm{pH}$ lower than 5.0, because of its $\mathrm{pH}$-dependent solubility (Fig. S7) [22, 24, 25, 37, 45]. Thus, the inhibition of crop growth observed at soil pH interval 5.0-6.0 (the optimal range for plant growth) might be mainly due to Ca deficiency rather than Al toxicity, as evidenced by Fig. S7. Obviously, the determination of the critical parameters such as Exch. $\mathrm{Al}$ and $\mathrm{Al}$ saturation, based on the intersection of crop response curves (viz., $90 \%$ of the maximum yield), were unreasonable due to showing much less or no effects. In this way, it is seemingly more reasonable to use Critical $\mathrm{Ca}: \mathrm{Al}$ ratio values to predict soil improvement [9, 30, 33, 40, 46], because the index would ensure that lime recommendations based on $\mathrm{Al}$ saturation provided adequate amounts of Ca for good plant growth [46]. However, our results showed that there was a lower relationship between Exch. $\mathrm{Al}$ : Ca ratio and crop yield (Table 4), which yielded an increased estimation error of critical $\mathrm{Al}$ : Ca ratio (Table 5). Ca saturation index rather than Exch. Al : Ca ratio should be paid more attention in determination of lime and nutrient requirements in acidic soils for good crop production in future studies, or in view of a strong correlation $\left(R^{2}=0.91\right)$ between $\mathrm{Ca}$ and $\mathrm{Al}$ saturation) [46], it seems feasible to obtain the critical values of $\mathrm{Al}$ saturation and thus Exch. $\mathrm{Al}: \mathrm{Ca}$ ratio (see the following section). 


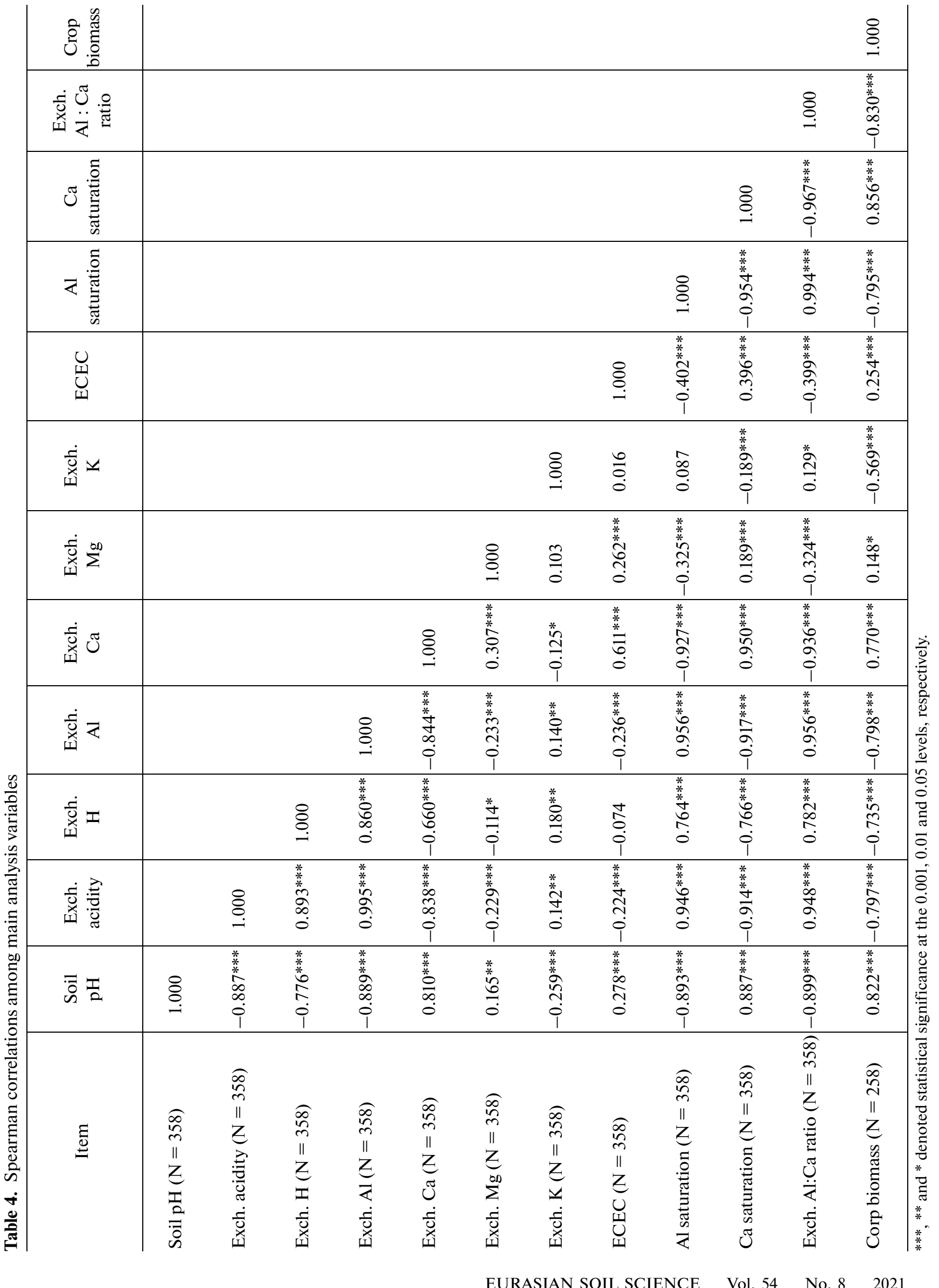




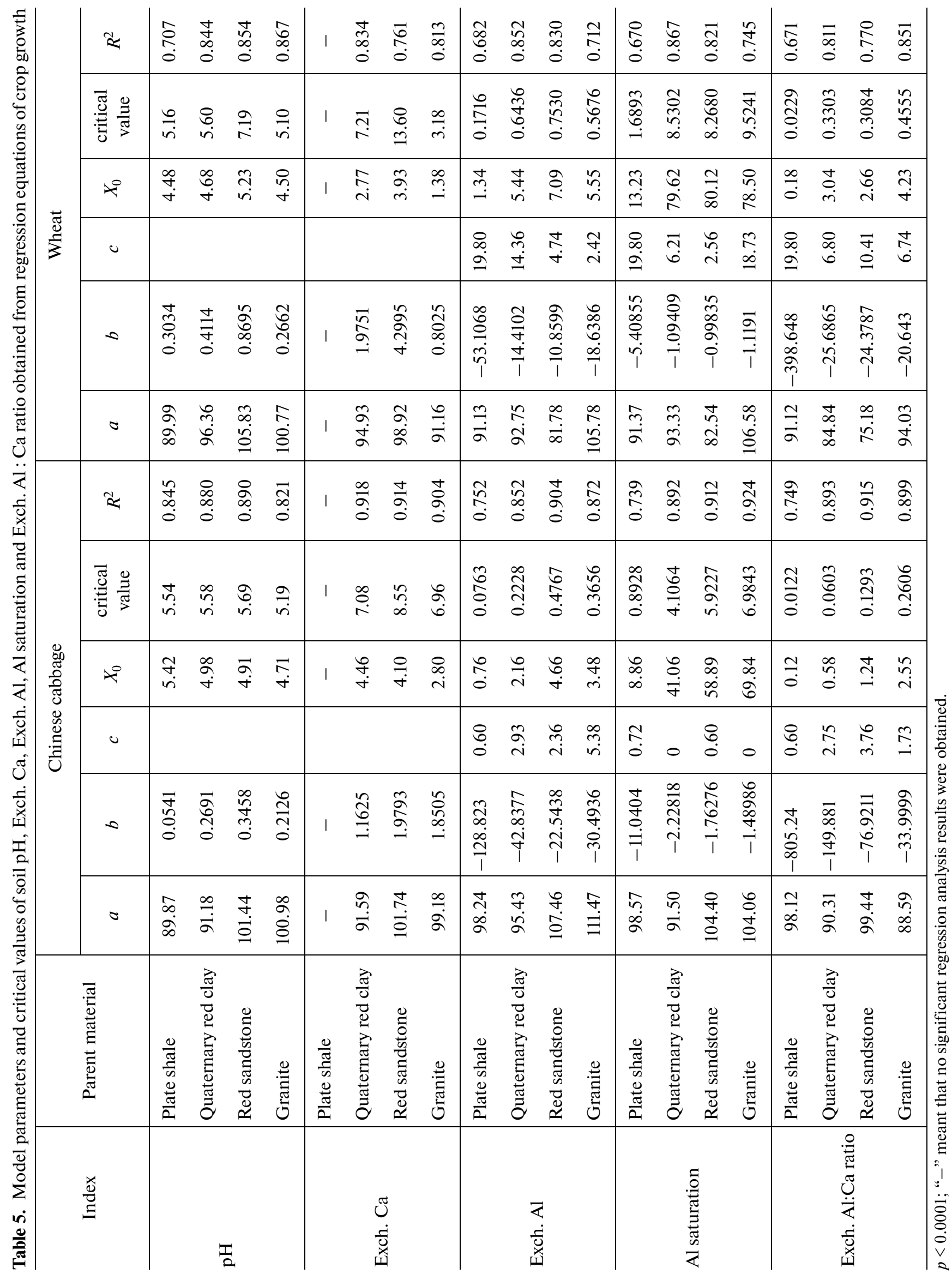




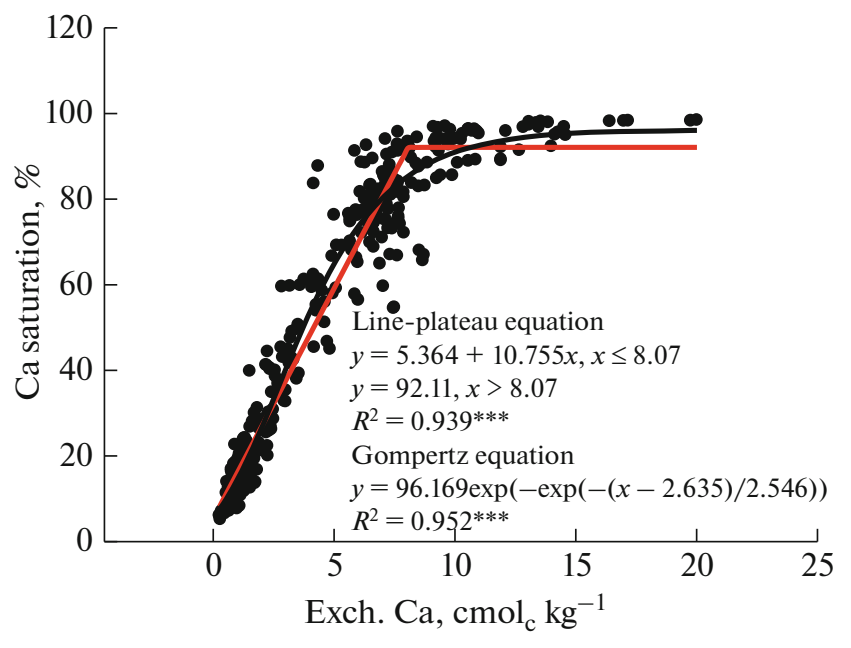

Fig. 4. Observed (symbol) and predicted (lines) relationship between Ca saturation and Exch. Ca in Ultisols.

The feasibility of critical Ca saturation. Our results showed that Ca saturation was the most important factor determining crop production in acidic soils; more and more researches also showed that soil Ca played an important role in alleviating $\mathrm{Al}$ toxicity and promoting nutrient availability of acidic soils $[6,7,33,37,46]$. In general, Ca saturation was a better indicator for cropsoil relationships than Exch. Ca content, because the latter varied extensively in various soils with different CEC while the former nearly eliminated the variations in different soils.

Line-plateau and Gompertz equations were used to model the relationship between $\mathrm{Ca}$ saturation and Exch. Ca and fitted well to the relationship $\left(R^{2}=0.939\right.$ and $R^{2}=0.952$, respectively) (Fig. 4), where critical Exch. Ca was determined as 8.07 and $8.36 \mathrm{cmol}_{\mathrm{c}} \mathrm{kg}^{-1}$, respectively (very similar to each other). Our previous study [52] showed that although liming increased crop yields in acidic soils, maintaining soil Exch. Ca value about $6.2 \mathrm{cmol}_{\mathrm{c}} \mathrm{kg}^{-1}$ was necessary for maximum yield. In addition, the field investigation in Qiyang County (data no published) showed almost the same relationship between $\mathrm{Ca}$ saturation and Exch. $\mathrm{Ca}$, and the critical Exch. Ca values obtained were 8.23 and $9.91 \mathrm{cmol}_{\mathrm{c}} \mathrm{kg}^{-1}$ (average $9.07 \mathrm{cmol}_{\mathrm{c}} \mathrm{kg}^{-1}$ ), which was consistent with those obtained in this study. Moreover, it was well established that approximately $87.5 \%$ of soils on arable lands in Qiyang County, was expected to require calcium supplementation for good crop yield, which was close to the value of $80 \%$ calculated according to soil acidification in this region (data no published). These consistent results further reinforced the notion that critical Ca saturation could be used as a reliable indicator to estimate the health of acidic soils.

The average critical value of Exch. Ca was $8.21 \mathrm{cmol}_{\mathrm{c}} \mathrm{kg}^{-1}$ in Ultisols, which was much lower than those proposed previously $[2,51]$. The possible reason was that rice adapted to lower soil $\mathrm{pH}$ (e.g., 4.9) than dry land crops such as wheat and maize [12, 57, 59], resulting in its higher $\mathrm{Al}$ tolerance and lower $\mathrm{Ca}$ requirement. Therefore, critical Exch. Ca might be as low as $1.2 \mathrm{cmol}_{\mathrm{c}} \mathrm{kg}^{-1}$. The critical value of Exch. Ca proposed by Wei et al. [51] was used to identify soils where response to Ca fertilization should be expected. That is, this was the lowest Exch. Ca requirement for crop growth (about $10 \%$ of the maximum yield), not the same concept as described in this study, where higher Exch. Ca requirement was used to maintain higher crop production ( $90 \%$ of the maximum yield). According to Figs. 3 and 4, the lowest critical Exch. Ca for $10 \%$ maximum yield (corresponding to $15-20 \%$ Ca saturation) was determined as $1.20 \mathrm{cmol}_{\mathrm{c}} \mathrm{kg}^{-1}$ $\left(0.90-1.36 \mathrm{cmol}_{\mathrm{c}} \mathrm{kg}^{-1}\right.$ and $1.06-1.49 \mathrm{cmol}_{\mathrm{c}} \mathrm{kg}^{-1}$, respectively). These data were also very consistent with previous observation in Ultisols [51].

There was strong linear correlation $\left(R^{2}=0.967, P<\right.$ $0.0001)$ between $\mathrm{Al}$ and $\mathrm{Ca}$ saturation, and the regression equation based on 358 observations was as follows:

$$
\mathrm{Al} \text { saturation } \%=84.55-0.94 \text { (Ca saturation \%). }
$$

There was essentially a $1: 1$ relationship, in agreement with the estimate by Smyth and Cravo [46]. The critical $\mathrm{Al}$ saturation in Ultisols was estimated to be $6.37 \%$, and hence critical $\mathrm{Al}: \mathrm{Ca}$ ratio $(\mathrm{Ca}: \mathrm{Al}$ ratio) was equal to 0.077 (13.0). Similarly, using the strong non-linear correlations between $\mathrm{Ca}$ saturation and Exch. $\mathrm{Al}$ and Exch. $\mathrm{Al}: \mathrm{Ca}$ ratio $\left(R^{2}=0.922\right.$ and $R^{2}=$ 0.977, respectively) (Fig. S8), critical Exch. Al value was determined as $0.44 \mathrm{cmol}_{\mathrm{c}} \mathrm{kg}^{-1}$, and the corresponding critical $\mathrm{Al}: \mathrm{Ca}$ ratio $(\mathrm{Ca}: \mathrm{Al}$ ratio) was 0.054 (18.6). Moreover, a critical Exch. $\mathrm{Al}: \mathrm{Ca}$ ratio $(\mathrm{Ca}: \mathrm{Al}$ ratio) of 0.069 (14.5) in Ultisols could be directly obtained from the regression equation. These results were consistent and in good agreement with those reported previously by Nora et al. [34], who showed that it was more appropriate to use a maximum $\mathrm{Al}$ saturation value of $5 \%$ (instead of current recommendation of $10 \%$ ) as the critical level for cereals on subtropical notillage soils. Additionally, these results were more accurate than those obtained from regression equations developed between crop yield and soil acidity indices, as shown in Table 5. Critical Ca saturation would no doubt be the best indicator to evaluate the implementation of quality improvements of acidic soils for good crop production, and it either alone or in combination with other indicators obtained according to the regression equations, such as $\mathrm{Al}$ saturation and Exch. $\mathrm{Al}$ : Ca ratio, has the potential to enhance a wide range of practical performance of soil management and crop production.

\section{CONCLUSIONS}

Structural equation modeling (SEM) and stepwise regression analysis evidenced that $\mathrm{Ca}$ saturation had the greatest direct effect on crop biomass, with high 
linear correlation between them, and thus was the most important factor that contributed to crop production in acidic soils. The determined critical values of Ca saturation varied slightly with crops and soils, with a higher difference between soils in variance of $6.5 \%$, that is, $84.6,93.5,95.2$ and $82.9 \%$ for Ultisols derived from plate shale, Quaternary red clay, red sandstone, and granite, respectively. This suggested that maintaining above a critical minimum Ca saturation of $83 \%$ in Ultisols was crucial important for the achievement of high crop yield. Our results also indicated that other soil acidity indices such as soil $\mathrm{pH}$, Exch. Al, and Exch. Ca: Al ratio were not good indicators for characterization of crop production with higher identifying bias and lower fitting precision. In conclusion, our study showed that critical Ca saturation was the best indicator for evaluating the implementation of quality improvement of acidic soils in Southern China, and it either alone or in combination with other indicators has a broad practical application of ameliorating acidity and optimizing crop yield in the future. For this purpose, additional recommendation criteria were listed as follows: Exch. $\mathrm{Ca}>8.21 \mathrm{cmol}_{\mathrm{c}} \mathrm{kg}^{-1}$, Exch. $\mathrm{Al}<$ $0.44 \mathrm{cmol}_{\mathrm{c}} \mathrm{kg}^{-1}, \mathrm{Al}$ saturation $<6.37 \%$ and Exch. $\mathrm{Al}: \mathrm{Ca}$ ratio $<0.069$ (or $\mathrm{Ca}: \mathrm{Al}$ ratio $>14.5$ ) for the $0-20 \mathrm{~cm}$ layer of Ultisols.

\section{FUNDING}

This work was financially supported by the National Natural Science Foundation of China $(31670471,41271254)$, Chinese Postdoctoral Science Foundation (2015M571178) and high-level talent project of Ludong University. The authors thank Professor Minggang Xu, Boren Wang and Shilin Wen from Red Soil Experimental Station (Chinese Academy of Agricultural Sciences) for their assistance during soil sampling and all the experimental process. The authors would also like to thank the anonymous reviewers and editors for helpful comments and constructive advice on this manuscript.

\section{CONFLICT OF INTEREST}

The authors declare that they have no competing financial interests.

\section{SUPPLEMENRARY INFORMATION}

The online version contains supplementary material available at doi 10.1134/S1064229321080020 and are accessible for authorized users.

Table S1. Basic properties of Ultisols 1 derived from different parent materials.

Table S2. Comparison of critical values of Exch. Al : Ca ratio (or Exch. $\mathrm{Ca}$ : Al ratio) obtained by different methods.

Fig. S1. Frequency histograms of soil acidity indices and crop relative dry weight.

Fig. S2. Shoot dry weight of Chinese cabbage and wheat as function of soil $\mathrm{pH}$ after crop harvest. Solid lines are the fits of Gompertz equations to the data $\left(R^{2}=0.71 \sim 0.89\right.$, $p<0.0001$ ).

Fig. S3. Shoot dry weight of Chinese cabbage and wheat as function of soil Exch. Ca. Solid lines are the fits of Gompertz equations to the data except for plate shale $\left(R^{2}=0.76-0.92, p<0.0001\right)$.

Fig. S4. Shoot dry weight of Chinese cabbage and wheat as function of soil Exch. Al. Solid lines are the fits of linearplateau model to the data $\left(R^{2}=0.68-0.90, p<0.0001\right)$.

Fig. S5. Shoot dry weight of Chinese cabbage and wheat as function of soil Al saturation. Solid lines are the fits of linear-plateau model to the data $\left(R^{2}=0.67-0.92, p<0.0001\right)$.

Fig. S6. Shoot dry weight of Chinese cabbage and wheat as function of soil Exch. Al : Ca ratio. Solid lines are the fits of linear-plateau model to the data $\left(R^{2}=0.67-0.92, p<0.0001\right)$.

Fig. S7. Changes of Exch. $\mathrm{Al}$, Exch. $\mathrm{Ca}$, and $\mathrm{Al}$ and $\mathrm{Ca}$ saturation with soil $\mathrm{pH}$ in Ultisols derived from different parent materials. Solid lines are the fits of linear-plateau or Gompertz model to the data, except for Exch. Ca in plate shale $\left(R^{2}=0.76-0.94, p<0.0001\right)$.

Fig. S8. Changes of Ca saturation with Exch. $\mathrm{Al}$ (a) and Exch. $\mathrm{Al}$ : Ca ratio (b) in Ultisols derived from different parent materials.

\section{REFERENCES}

1. R. L. Aitken and P. W. Moody, "The effect of valence and ionic-strength on the measurement of $\mathrm{pH}$ buffer capacity,” Aust. J. Soil Res. 32 (5), 975-984 (1994). https://doi.org/10.1071/SR9940975

2. E. A. Azman, S. Jusop, C. F. Ishak, and R. Ismail, "Increasing rice production using different lime sources on an acid sulphate soil in Merbok, Malaysia," Pertanika J. Trop. Agric. Sci. 37 (2), 223-247 (2014). http://www.pertanika.upm.edu.my/Pertanika\%20PAPERS/JTAS\%20Vol.\%2037\%20(2)\%20May.\%202014/ 04\%20Page\%20223\%20to\%20248\%20(JTAS\%2004942013).pdf.

3. M. A. A. Baquy, J. Y. Li, C. Y. Xu, K. Mehmood, and R. K. Xu, "Determination of critical $\mathrm{pH}$ and $\mathrm{Al}$ concentration of acidic ultisols for wheat and canola crops," Solid Earth 8, 149-159 (2017). https://doi.org/10.5194/se-8-149-2017

4. M. A. A. Baquy, J. Y. Li, J. Jiang, K. Mehmood, R. Y. Shi, and R. K. Xu, "Critical pH and exchangeable $\mathrm{Al}$ of four acidic soils derived from different parent materials for maize crops," J. Soils Sediments 18, 14901499 (2018). https://doi.org/10.1007/s11368-017-1887-x

5. M. A. A. Baquy, J. Y. Li, R. Y. Shi, M. A. Kamran, and R. K. Xu, "Higher cation exchange capacity determined lower critical soil $\mathrm{pH}$ and higher Al concentration for soybean," Environ. Sci. Pollut. Res. 25, 69806989 (2018). https://doi.org/10.1007/s11356-017-1014-y

6. S. K. Behera, A. K. Shukla, B. S. Dwivedi, A. Cerda, and B. L. Lakaria, "Alleviating soil acidity: optimization of lime and zinc use in maize (Zea mays L.) grown on alfisols," Commun. Soil Sci. Plant Anal. 51 (2), $221-235$ (2020).

https://doi.org/10.1080/00103624.2019.1705322 
7. E. F. Caires, J. C. L. Corrêa, S. Churka, G. Barth, and F. J. Garbuio, "Surface application of lime ameliorates subsoil acidity and improves root growth and yield of wheat in an acid soil under no-till system," Sci. Agric. 63 (5), 502-509 (2006).

https://doi.org/10.1590/S0103-90162006000500013

8. China Geological Survey, A geochemical survey report on China's cultivated lands, 2015. http://www.ngac.cn/ Public/AttachFile/201506/20150626094736c626.pdf.

9. C. S. Cronan and D. F. Grigal, "Use of calcium/aluminum ratios as indicators of stress in forest ecosystems," J. Environ. Qual. 24 (2), 209-226 (1995). https://doi.org/10.2134/jeq1995.00472425002400020002x

10. M. I. Diel, B. G. Sari, D. K. Krysczun, T. Olivoto, M. V. M. Pinheiro, D. Meira, D. Schmidt, and A. D. Lúcio, "Nonlinear regression for description of strawberry (Fragaria x ananassa) production," J. Hortic. Sci. Biotechnol. 94 (2), 259-273 (2019). https://doi.org/10.1080/14620316.2018.1472045

11. N. Eisenhauer, M. A. Bowker, J. B. Grace, and J. R. Powell, "From patterns to causal understanding: structural equation modeling (SEM) in soil ecology," Pedobiologia 58 (2-3), 65-72 (2015). https://doi.org/10.1016/j.pedobi.2015.03.002

12. N. K. Fageria and V. C. Baligar, "Growth and nutrient concentrations of common bean, lowland rice, corn, soybean, and wheat at different soil $\mathrm{pH}$ on an Inceptisol," J. Plant Nutr. 22 (9), 1495-1507 (1999). https://doi.org/10.1080/01904169909365730

13. N. K. Fageria and V. C. Baligar, "Fertility management of tropical acid soils for sustainable crop production," in Handbook of Soil Acidity, Ed. by Z. Rengel (Marcel Dekker, New York, 2003), pp. 359-385. https://doi.org/10.1201/9780203912317.ch13

14. N. K. Fageria and V. C. Baligar, "Ameliorating soil acidity of tropical oxisols by liming for sustainable crop production," Adv. Agron. 99, 345-399 (2008). https://doi.org/10.1016/S0065-2113(08)00407-0

15. E. Fekadu, K. Kibret, B. Bedadi, and A. Melese, "Characterization and classification of soils of Yikalo subwatershed in Lay Gayint district, Northwestern Highlands of Ethiopia," Eurasian J. Soil Sci. 7 (2), 151-166 (2018). https://doi.org/10.18393/ejss.376267

16. E. Fekadu, K. Kibret, B. Bedadi, A. Melese, and B. Yitaferu, "Organic and inorganic amendments on soil chemical properties at different period of incubation of acidic soil,” Eur. J. Soil Sci. 7 (3), 273-283 (2018). https://doi.org/10.18393/ejss.435095

17. S. M. V. Fontoura, O. H. de Castro Pias, T. Tiecher, M. R. Cherubin, R. P. de Moraes, and C. Bayer, "Effect of gypsum rates and lime with different reactivity on soil acidity and crop grain yields in a subtropical oxisol under no-tillage," Soil Tillage Res. 193, 27-41 (2019). https://doi.org/10.1016/j.still.2019.05.005

18. C. Gülser, Z. Zharlygasov, R. Kizilkaya, N. Kalimov, I. Akça, and Z. Zharlygasov, "The effect of NPK foliar fertilization on yield and macronutrient content of grain in wheat under Kostanai-Kazakhstan conditions,” Eur. J. Soil Sci. 8 (3), 275-281 (2019). https://doi.org/10.18393/ejss.575026

19. W. L. Guo, H. Nazim, Z. S. Liang, and D. F. Yang, "Magnesium deficiency in plants: an urgent problem," Crop J. 4 (2), 83-91 (2016).

https://doi.org/10.1016/j.cj.2015.11.003
20. K. Hagvall, P. Persson, and T. Karlsson, "Speciation of aluminum in soils and stream waters: the importance of organic matter," Chem. Geol. 417, 32-43 (2015). https://doi.org/10.1016/j.chemgeo.2015.09.012

21. H. Hamzehzarghani and S. A. Kazemeini, "An analysis of the exponential family models to predict yield loss of safflower (Carthamus tinctorius L.) challenged with water stress and redroot pigweed (Amaranthus retroflexus L.)," J. Agric. Sci. Technol. 13 (7), 989-1000 (2011). http://jast.modares.ac.ir/article-23-4053-en.html.

22. R. J. Haynes and M. S. Mokolobate, "Amelioration of $\mathrm{Al}$ toxicity and $\mathrm{P}$ deficiency in acid soils by additions of organic residues: a critical review of the phenomenon and the mechanisms involved," Nutr. Cycling Agroecosyst. 59, 47-63 (2001). https://doi.org/10.1023/A:1009823600950

23. S. L. Hoe, "Issues and procedures in adopting structural equation modeling technique," J. Appl. Quant. Methods 3 (1), 76-83 (2008). http://jaqm.ro/issues/volume-3, issue-1/pdfs/hoe.pdf.

24. S. J. Kemmitt, D. Wright, K. W. T Goulding, and D. L. Jones " $p H$ regulation of carbon and nitrogen dynamics in two agricultural soils," Soil Biol. Biochem. 38 (5), 898-911(2006). https://doi.org/10.1016/j.soilbio.2005.08.006

25. L. V. Kochian, M. A. Piñeros, J. P. Liu, and J. V. Magalhaes, "Plant adaptation to acid soils: the molecular basis for crop aluminum resistance," Annu. Rev. Plant Biol. 66, 571-598 (2015). https://doi.org/10.1146/annurev-arplant-043014-114822

26. E. G. Lamb, N. Kennedy, and S. D. Siciliano, "Effects of plant species richness and evenness on soil microbial community diversity and function," Plant Soil 338, 483-495 (2011). https://doi.org/10.1007/s11104-010-0560-6

27. Y. Lin, D. B. Watts, H. A. Torbert, and J. A. Howe, "Influence of nitrogen rate on winter canola production in the southeastern United States," Agron. J. 112 (4), 2978-2987 (2020). https://doi.org/10.1002/agj2.20197

28. D. L. Liu, K. R. Helyar, M. K. Conyers, R. Fisher, and G. J. Poile, "Response of wheat, triticale and barley to lime application in semi-arid soils," Field Crops Res. 90 (2-3), 287-301 (2004).

https://doi.org/10.1016/j.fcr.2004.03.008

29. R. K. Lu, Analysis Methods in Soil Agrochemistry (Chinese Agricultural Science and Technology Press, Beijing, 2000). ISBN 7-80119-925-1

30. J. Lyon and W. E. Sharpe, "An assessment of the Ca:Al ratios of selected Pennsylvania forest soils," Water, Air Soil Pollut. 109, 53-65 (1999). https://doi.org/10.1023/A:1005042426912

31. R. L. Mahler and R. E. McDole, "Effect of soil pH on crop yield in northern Idaho,” Agron. J. 79 (4), $751-$ 755 (1987).

https://doi.org/10.2134/agronj1987.000219620079000 40033x

32. K. Manikandan and P. I. Vethamoni, "A review: crop modeling in vegetable crops," J. Pharmacogn. Phytochem. 6 (4), 1006-1009 (2017). https://www.phytojournal.com/ archives/2017/vol6issue4/PartO/6-4-4-958.pdf.

33. P. Narhi, M. Middleton, N. Gustavsson, E. Hyvonen, M. Sutinen, and R. Sutinen, "Importance of soil calcium for composition of understory vegetation in boreal forests of Finnish Lapland," Biogeochemistry 102, 
239-249 (2011). https://doi.org/10.1007/s10533-010-9437-2

34. D. D. Nora, T. J. C. Amado, R. S. Nicoloso, and E. M. Gruhn, "Modern high-yielding maize, wheat and soybean cultivars in response to gypsum and lime application on no-till oxisol," Rev. Bras. Ciên. Solo 41, e0160504 (2017). https://doi.org/10.1590/18069657rbcs20160504

35. F. J. Pierce and D. D. Warncke, "Soil and crop response to variable-rate liming for two Michigan fields," Soil Sci. Soc. Am. J. 64 (2), 774-780 (2000). https://doi.org/10.2136/sssaj2000.642774x

36. R. J. Qin and F. X. Chen, "The aluminum toxicity of some crop seedlings in red soil of Southern Hunan," Plant Nutr. Fertil. Sci. 5 (1), 50-55 (1999). https://doi.org/10.11674/zwyf.1999.0109

37. M. A. Rahman, S. H. Lee, H. C. Ji, A. H. Kabir, C. P. Jones, and K. W. Lee, "Importance of mineral nutrition for mitigating aluminum toxicity in plants on acidic soils: current status and opportunities," Int. J. Mol. Sci. 19 (10), 3073 (2018).

https://doi.org/10.3390/ijms19103073

38. M. C. Rillig, S. F. Wright, and V. T. Eviner, "The role of arbuscular mycorrhizal fungi and glomalin in soil aggregation: comparing effects of five plant species," Plant Soil 238, 325-333 (2002). https://doi.org/10.1023/A:1014483303813

39. A. Ringuelet and O. A. Bachmeier, "Kinetics of soil nitrogen mineralization from undisturbed and disturbed soil," Commun. Soil Sci. Plant Anal. 33 (19-20), 3703-3721 (2002). https://doi.org/10.1081/CSS-120015916

40. P. G. Schaberg, J. W. Tilley, G. J. Hawley, D. H. DeHayes, and S. W. Bailey, "Associations of calcium and aluminum with the growth and health of sugar maple trees in Vermont," For. Ecol. Manage. 223 (1-3), 159169 (2006). https://doi.org/10.1016/j.foreco.2005.10.067

41. J. Shamshuddin, C. I. Fauziah, M. Anda, J. Kapok, and M. A. R. S. Shazana, "Using ground basalt and/or organic fertilizer to enhance productivity of acid soils in Malaysia for crop production," Mal. J. Soil Sci. 15, 127-146 (2011). http://www.msss.com.my/mjss/Full\% 20Text/Vol\%2015/shamsuddin.pdf.

42. J. Shamshuddin, H. A. H. Sharifuddin, and L. C. Bell, "Longevity of ground magnesium limestone applied to an ultisol," Commun. Soil Sci. Plant Anal. 29 (9-10), 1299-1313 (1998). https://doi.org/10.1080/00103629809370027

43. R. Y. Shi, Z. D. Liu, Y. Li, T. M. Jiang, M. G. Xu, J. Y. Li, and R. K. Xu, "Mechanisms for increasing soil resistance to acidification by long-term manure application,” Soil Tillage Res. 185, 77-84 (2019). https://doi.org/10.1016/j.still.2018.09.004

44. W. C. Shortle and K. T. Smith, "Aluminum-induced calcium deficiency syndrome in declining red spruce," Science 240 (4855), 1017-1018 (1988).

https://doi.org/10.1126/Sci..240.4855.1017

45. S. Singh, D. K. Tripathi, S. Singh, S. Sharma, N. K. Dubey, D. K. Chauhan, and M. Vaculík, "Toxicity of aluminum on various levels of plant cells and organism: a review," Environ. Exp. Bot. 137, 177-193 (2017). https://doi.org/10.1016/j.envexpbot.2017.01.005

46. T. J. Smyth and M. S. Cravo, "Aluminum and calcium constraints to continuous crop production in a Brazil- ian Amazon oxisol,” Agron. J. 84 (5), 843-850 (1992). https://doi.org/10.2134/agronj1992.000219620084000 50016x

47. M. R. Soares and L. R. F. Alleoni, "Contribution of soil organic carbon to the ion exchange capacity of tropical soils," J. Sustainable Agric. 32 (3), 439-462 (2008). https://doi.org/10.1080/10440040802257348

48. A. Sutradhar, R. P. Lollato, K. Butchee, and D. B. Arnall, "Determining critical soil $\mathrm{pH}$ for sunflower production," Int. J. Agron. 2014, 1-13 (2014). https://doi.org/10.1155/2014/894196

49. K. Z. Tan and W. G. Keltjens, "Analysis of acid-soil stress in sorghum genotypes with emphasis on aluminum and magnesium interactions," Plant Soil 171, $147-150$ (1995). https://doi.org/10.1007/BF00009578

50. X. Tang, Y. Ma, X. Hao, X. Li, J. Li, S. Huang, and $\mathrm{X}$. Yang, "Determining critical values of soil Olsen-P for maize and winter wheat from long-term experiments in China," Plant Soil 323, 143-151 (2009). https://doi.org/10.1007/s11104-009-9919-y

51. S. X. Wei, Z. S. Xie, Z. Y. Li, J. J. Xie, S. R. Luo, and Y. Y. Chen, "Soil fertility investigation and evaluation for banana gardens in Guangxi," Chin. J. Trop. Crops 33 (8), 1371-1377 (2012). http://en.cnki.com.cn/Article_en/CJFDTOTAL-RDZX201208008.htm

52. T. T. Zeng, Z. J. Cai, X. L. Wang, W. J. Liang, S. W. Zhou, and M. G. Xu, "Integrated analysis of liming for increasing crop yield in acidic soils," Sci. Agric. Sin. 50 (13), 2519-2527 (2017).

https://doi.org/10.3864/j.issn.0578-1752.2017.13.011

53. G. Zhang, Q. F. Zhu, X. S. Guo, Z. H. Xiang, S. J.,Wang, S. D. Shen, and X. J. Ji, "Amelioration of dolomite on acidity of flue-cured tobacco soil in South Anhui," Soils 46 (3), 534-538 (2014). http://soils.issas. ac.cn/tr/ch/reader/view_abstract.aspx?file_no=tr201403085.

54. T. Zhang, H. Y. H. Chen, and H. Ruan, "Global negative effects of nitrogen deposition on soil microbes," ISME J. 12, 1817-1825 (2018). https://doi.org/10.1038/s41396-018-0096-y

55. K. L. Zhao, B. R. Wang, M. G. Xu, Z. J. Cai, W. Q. Shi, and H. Y. Ma, "Changes in $\mathrm{pH}$ with depths of soils derived from different parent materials and analysis of acidification in Southern China," J. Plant Nutr. Fertil. 25 (8), 1308-1315 (2019). https://doi.org/10.11674/zwyf.18143

56. W. Zhao, R. Zhang, H. Cao, and W. Tan, "Factor contribution to soil organic and inorganic carbon accumulation in the Loess Plateau: structural equation modeling," Geoderma 352, 116-125 (2019). https://doi.org/10.1016/j.geoderma.2019.06.005

57. S. W. Zhou, PhD Thesis (Institute of Agricultural Resources and Regional Planning, Chinese Academy of Agricultural Sciences, Beijing, 2017).

58. H. F. Zhu, Y. Zhao, F. Nan, Y. H. Duan, and R. T. Bi, "Relative influence of soil chemistry and topography on soil available micronutrients by structural equation modeling,” J. Soil Sci. Plant Nutr. 16 (4), 1038-1051 (2016). https://doi.org/10.4067/S0718-95162016005000076

59. Q. C. Zhu, X. J. Liu, T. X. Hao, M. F. Zeng, J. B. Shen, F. S. Zhang, and W. Vries, "Cropland acidification increases risk of yield losses and food insecurity in China," Environ. Pollut. 256, 113145 (2020). https://doi.org/10.1016/j.envpol.2019.113145 